\title{
Rooting of olive minicuttings at different seasons grown in clonal minigarden
}

\author{
Josiane Vergara Casarin*, Aline Ramm, Carlos Gustavo Raasch, \\ Cari Rejane Fiss Timm, Márcia Wulff Schuch
}

Federal University of Pelotas, Pelotas, RS, Brazil.

*Corresponding author, e-mail: josiane.casarin@hotmail.com

\begin{abstract}
The objectives were: a) to evaluate the initial development of olive ministumps in semi-hydroponic and conventional systems; b) evaluate the productivity ministumps in successive collections and the rooting of minicuttings of olive tree collected at different times of the year clonal mini garden cultivated in semi-hydroponic and conventional systems. The cultivation systems used were the semi-hydroponics and conventional, to which was evaluated for 90 days of cultivation the initial growth of ministumps. After that began the collection of plant material in cropping systems. The variables analyzed were: the initial growth of ministumps, productivity, the percentage of survival and rooting, the number and length of roots and also found the survival of rooted minicuttings of cropping systems. The cultivation of olive ministumps in semi-hydroponic system is more efficient in minicuttings productivity than the conventional system. The minicuttings collected in separate semi-hydroponic system collecting time showed the best results for the variables analyzed in relation to the conventional system of cultivation.
\end{abstract}

Keywords: fruit growing, Olea europaea L., propagation, cropping system

\section{Introduction}

In South America, Argentina and Chile are the main producers and exporters of olives and olive oil, respectively (Silva et al., 2012a). Brazil is considered one of the world's biggest importers of olives and derivates (Oliveira et al., 2012a). Oliviculture in Brazil is a recent and expanding agricultural activity (Oliveira et al., 2009).

The production of quality olive seedlings is an important link in the productive chain for the development of trustworthy propagative material, since it constitutes the first step for the implantation of olive crops. The acquirement of quality seedlings, more than guarantying uniformity and varietal suitability, represents a factor which influences the orchard's entire productive life, allowing to maximize the effects of climate and soil and mainly of cultivation practices adopted in the crop (Oliveira et al., 2010).

Clonal gardens are orchards composed by one or several groups of plants, whose purpose is the production of propagules for the formation of quality seedlings, intended for the implantation of orchards and commercial nurseries (Cavalcanti Júnior, 2000). Clonal gardens are made by plants entitled ministumps, from which the minicuttings are collected (Rocha et al., 2013). The utilization of clonal mini gardens for cutting production has been adopted for a variety of crops, like: bilberry 
(Nascimento et al., 2011; Affonso et al., 2015), guava (Altoé et al., 2011), eucalyptus (Cunha et al., 2009; Rocha et al., 2013), Australian redcedar (Silva et al., 2012) and angico-vermelho (Dias et al., 2012), and, among them, olive (Oliveira et al., 2010). The advantage of this technique lies in the fact that, while a sole matrix provides us a limited amount of propagules, clonal gardens enable the offer of a greater amount of propagative material, genetically identical to the parent plant (Cavalcanti Júnior, 2000).

According to Dias et al. (2012), several factors influence the rooting of minicuttings, with emphasis, among them, to the season of the year. According to the environmental variations and with the characteristic of each season there may occur variations in the ministumps budding production and minicuttings rooting. According to Ferriani et al. (2011), the species Piptocarpha angustifolia presents a greater budding in the winter. To Cappellaro (2013), minicuttings of olive cultivar Arbequina present a better rooting in spring and summer, being the winter the season with the smallest rooting percentage.

Therefore, the aims of this work were: to evaluate the initial development of olive ministumps in the semi-hydroponic and conventional systems; to evaluate ministumps productivity in successive collections and the rooting of olive minicuttings, collected in different seasons from clonal mini garden cultivation in the semi-hydroponic and conventional systems.

\section{Materials and Methods}

The experiment was conducted in a plastic greenhouse belonging to the LabAgro of Departamento de Fitotecnia da Faculdade de Agronomia Eliseu Maciel of Federal University of Pelotas, in the time between January 2013 to September 2014.

The clonal mini garden was formed in two cropping systems: semi-hydroponic and conventional. The semi-hydroponic system was composed by trapezoidal-shape flower pots filled with a $5 \mathrm{~cm}$ layer of average gravel stone at the bottom, and over it, as substratum, sand of an average granulometry 10,50 a 0,250 $\mathrm{mm}$ ) previously washed with rain water. The employed ministumps were produced through the rooting of minicuttings. The system was constituted by 12 ministumps per flowerpot, with a $0,10 \times 0,10 \mathrm{~cm}$ spacing. The seedlings were daily manually irrigated with the aid of a watering can containing approximately one litter of nutritive solution per flower pot, formulated by Schuch \& Peil (2012), accordingly with to the needs of the olive crop. To avoid salinization in the semihydroponic cropping system, a lamina of rain water was fortnightly applied.

In the conventional system the ministumps were inserted in polyethylene plastic bags containing Carolina Soil ${ }^{\circledR}$ substratum. The ministumps were individually distributed in each plastic bag, with a 0,10 $\times 0,10 \mathrm{~cm}$ spacing. The seedlings were manually irrigated daily with the aid of a watering can, with approximately $100 \mathrm{~mL}$ of rain water per bag, and at every 15 days a nutritive solution was provided.

The experiment was developed in three stages, described following:

The first stage consisted in the formation of the clonal mini garden with rooted minicuttings of the Arbequina cultivar, aiming the collection of propagative material from the olive ministumps: the experimental delimitation was the randomized complete block design, in a factorial arrangement of $2 \times 3$ (cropping systems $x$ evaluation dates) with four repetitions for each cropping system, constituted of 12 ministumps each. The data were subjected to the ShapiroWilk test, in order to gauge the normality of data; since they did not present a normal distribution, a transformation was performed, through the square root $x+0,5$ for the budding number. Following that the data were subjected to variance analysis, and the averages comparison was performed by Tukey's test at $5 \%$ probability of error, using the statistical software GENES (Cruz, 2013). At this stage the ministumps initial development was evaluated at 30, 60 and 90 days of cultivation to both systems, through the number of primary and secondary buddings, with the aid of a centimeters graduated ruler.

Second stage: for the collection seasons of both cropping systems a $2 \times 5$ factorial was made (cropping systems $x$ collecting seasons). The experimental delimitation was the randomized complete block design with four repetitions of 
30 minicuttings per each cropping system. The obtained data were subjected to variance analysis and averages comparison was realized by Tukey's test at $5 \%$ probability, through GENES software (Cruz, 2013). The data were subjected to the test of Shapiro-Wilk, to gauge the normality of the data. As they did not present normal distribution a transformation was performed, through the arc sen of the square root of $x / 100$ for the survival and rooting percentage, and square root of $x+0,5$ for the minicuttings productivity and number of roots.

After the last evaluation (at 90 days) the collect of the minicuttings at the clonal minigarden started. During the experiment's conduction period the productivity of each clonal minigarden was evaluated in the five collections, when the counting of buddings collected per ministumps was performed. The collections were performed in the autumn and spring of 2013, and the summer, spring and autumn of 2014, completing five collections for both cropping systems. After the materials collection the minicuttings were prepared, with $3-5 \mathrm{~cm}$, two pairs of gems and a leaf area reduction of $50 \%$. At the bottom of the minicuttings two superficial lesions were made and, posteriorly, immersed for ten seconds in a solution of indolebutyric acid (IBA) in the concentration of $3000 \mathrm{mgL}^{-1}$, and put in articulated transparent covered plastic boxes Sampack ${ }^{\circledR}$, containing average expanded vermiculite substratum. Following that, they were stowed in greenhouse with a controlled temperature of $25 \pm 2^{\circ} \mathrm{C}$ for 80 days. After this period, the following variables were analyzed: percentage of survival (minicuttings that remained alive, either presenting or not roots) and rooting (minicuttings with root primordia induction, with at least $1 \mathrm{~mm}$ of length), number of roots (considered only those originated directly from the minicuttings) and the root length per minicutting $(\mathrm{cm})$.

Leaf nutritional analysis of ministumps cultivated in both cropping systems was performed at the Soil's Chemistry Laboratory of Federal University of Pelotas.

Third stage: The experimental delimitation was the randomized complete block design with four repetitions constituted of 15 minicuttings from each cropping system. The obtained data were subjected to variance analysis, and averages comparison was realized by Tukey's test at $5 \%$ probability of error, through GENES software (Cruz, 2013). The data expressed in rooted minicuttings percentage of survival were transformed in arc sen of the square root of $x / 100$.

During the collection seasons the rooted minicuttings percentage of survival in the cropping systems was analyzed. Rooted minicuttings were transferred no polyethylene bags with a volumetric capacity of approximately $700 \mathrm{~mL}$ with $\mathrm{H}$ Decker ${ }^{\circledR}$ substratum. The seedlings were daily irrigated with rain water and fortnightly with nutritive solution, for a period of 90 days.

\section{Results and Discussion}

A significative interaction was observed between cropping systems and evaluation days for the number of primary buddings. For both systems, in the three evaluation dates, there were no significative differences. In the individual analysis at the semi-hydroponic and conventional systems, the higher number of primary buddings was obtained at 60 and 90 days of cultivation respectively. There was a significative interaction for the number of secondary buddings. In the analysis between cropping systems there was a significative difference only at 90 days of cultivation, with 3,18 buddings for the semihydroponic system and 0,50 for the conventional. In the comparison between evaluation days in the cropping systems there were no significative differences (Table 1).

In the interaction between systems and evaluation days there were statistical differences for the length of primary buddings. In the analysis between systems there are differences only at 90 days, occurring greater primary budding length in the semi-hydroponic, with $15,61 \mathrm{~cm}$, compared with the conventional, which had $6,54 \mathrm{~cm}$. In the analysis within evaluation days there were no significative differences for the conventional system, at the contrary of the semihydroponic system, where there are differences among evaluation days, with a greater length at 90 evaluation days, with $15,61 \mathrm{~cm}$ of length (Table 1). Results obtained by Batista et al. (2011), demonstrated that the budding number by 60 days of pomegranate cultivation (Punica 
granatum L.) was superior in coconut fiber substratum than in sand.

Within cropping systems there was a significative difference on data at 60 and 90 days. At 60 days the semi-hydroponic system presented 0,76 cm, and the conventional, 0,29 $\mathrm{cm}$. At 90 days the semi-hydroponic system

Table 1. Number of primary buddings, primary buddings length $(\mathrm{cm})$, number of secondary buddings and length of secondary buddings $(\mathrm{cm})$ in clonal mini garden of olive cultivar Arbequina in semi-hydroponic and conventional cropping systems. Pelotas-RS, Brazil

\begin{tabular}{cccc}
\hline \multicolumn{5}{c}{ Number of primary buddings } \\
\hline \multicolumn{5}{c}{ Evaluation days } \\
\hline Cropping system & 30 days & 60 days & 90 days \\
\hline Semi-hydroponic & $0,93 \mathrm{Ab}$ & $1,56 \mathrm{Aa}$ & $1,58 \mathrm{Aa}$ \\
Conventional & $1,02 \mathrm{Ab}$ & $1,50 \mathrm{Aa}$ & $1,52 \mathrm{Aa}$ \\
\hline CV(\%) & 8,53 & $15,61 \mathrm{Aa}$ \\
\hline \multicolumn{5}{c}{ Length of primary buddings $(\mathrm{cm})$} \\
\hline Semi-hydroponic & $2,36 \mathrm{Ab}$ & $6,00 \mathrm{Ab}$ & \\
Conventional & $2,76 \mathrm{Aa}$ & $5,30 \mathrm{Aa}$ \\
\hline CV(\%) & 55,86 & $3,18 \mathrm{Aa}$ \\
\hline Nemi-hydroponic & $0,50 \mathrm{Aa}$ & $0,50 \mathrm{Ba}$ \\
\hline Conventional & $0,46 \mathrm{Aa}$ & \\
\hline CV(\%) & 44,93 & $0,54 \mathrm{Aa}$ \\
\hline Lemi-hydroponic & $0,69 \mathrm{Ab}$ & $0,36 \mathrm{Ba}$ \\
\hline Conventional & $0,84 \mathrm{Aa}$ & $0,76 \mathrm{Ab}$ \\
\hline CV(\%) & 43,24 & $0,29 \mathrm{Ba}$ \\
\hline
\end{tabular}

*Averages followed by the same uppercase letters on vertical and lowercase on horizontal do not statistically differ between them by Tukey's test at $5 \%$ probability of error. $\mathrm{cm}$. - centimeters.

presented $1,38 \mathrm{~cm}$, and the conventional, $0,36 \mathrm{~cm}$. As to cultivation days there was no significative difference for secondary budding length. In the semi-hydroponic system, however, there were differences, with the obtaining of a higher value at 90 evaluation days, with $1,38 \mathrm{~cm}$ (Table 1).

Nascimento et al. (2011), in a work performed with bilberry (Vaccinium spp.) verified, at 30 cultivation days, differences between budding length, with 6,47 and $4,38 \mathrm{~cm}$, respectively, in cultivars Woodard and Bluebelle. At 90 cultivations days, it was verified that the semi-hydroponic system afforded a greater shoot length and budding number for both cultivars. According to the authors the supplyment of the nutritive solution in the semi-hydroponic system afforded a greater nutrients availability, promoting a better vegetative growth of the seedlings. In this work the semi-hydroponic system also afforded a greater ministumps growth.

In a work developed by Affonso (2011), with cattley guava microcuttings in conventional and semi-hydroponic cropping systems the variables budding number and secondary budding length did not present significative differences between cropping systems until 120 evaluation days. According to the author these results occurred due to temperature rise and longer duration of days, stimulating plant growth, and also that microcuttings were already adapted to the systems, allowing budding growth.

In the interaction between cropping systems and collection seasons for minicuttings productivity there were significative differences. The semi-hydroponic system had a greater minicuttings productivity than the conventional in the spring of 2013, summer, autumn and spring of 2014. Within collection seasons there was a significative difference for the semi-hydroponic cropping system with a greater productivity in spring and summer of 2014, with an average of 26,36 and 20,21 minicuttings, respectively. For the conventional cropping system there was no significative difference between collection seasons (Table 2).

As about seasons, the summer of 2014 and spring of 2013 and 2014 presented a greater productivity of minicuttings in the semi-hydroponic system. This fact could be explained by being these months those with 
Table 2. Ministumps productivity averages and minicuttings survival percentage of olive cultivar Arbequina in semihydroponic and conventional cropping systems in different seasons. Pelotas-RS, Brazil

\begin{tabular}{ccccc}
\hline \multirow{2}{*}{ Seasons/Collections year } & \multicolumn{2}{c}{ Productivity } & \multicolumn{2}{c}{ Survival (\%) } \\
\cline { 2 - 5 } & Semi-Hydroponic & Conventional & Semi-Hydroponic & Conventional \\
\hline Autumn/2013 & $7,48 \mathrm{Ab}$ & $2,88 \mathrm{Aa}$ & $86,75 \mathrm{Aa}$ & $34 \mathrm{Bb}$ \\
Spring/2013 & $11,38 \mathrm{Ab}$ & $1,96 \mathrm{Ba}$ & $71,75 \mathrm{Aa}$ & $17 \mathrm{Bb}$ \\
Summer/2014 & $20,21 \mathrm{Aa}$ & $2,5 \mathrm{Ba}$ & $75,25 \mathrm{Aa}$ & $15 \mathrm{Bb}$ \\
Autumn/2014 & $9,13 \mathrm{Ab}$ & $3,19 \mathrm{Ba}$ & $87,5 \mathrm{Aa}$ & $86 \mathrm{Aa}$ \\
Spring/2014 & $26,35 \mathrm{Aa}$ & $4,19 \mathrm{Ba}$ & $92,5 \mathrm{Aa}$ & $85 \mathrm{Aa}$ \\
\hline CV(\%) & \multicolumn{4}{c}{31,94} \\
\hline *Averages followed by the same uppercase letters on vertical and lowercase on horizontal do not statistically differ between them by Tukey's
\end{tabular}

test at $5 \%$ probability of error.

higher temperatures, favoring the vegetative growth of ministumps. Accodring Cunha et al. (2009), the minicuttings production of Eucalyptus spp., in clonal mini gardens, increases with the elevation of temperature. According to Affonso et al. (2015), the increase in the bilberry minicuttings production in clonal minigarden occurred in summer, since it is the season with a greater vegetative growth of the parent plants.

Differences in the productivity of minicuttings in different types of clonal mini gardens is another related factor reported by Silva et al. (2012), on which the authors found differences in minicuttings production, in gutter and tube systems. During the collection period there was no productivity drop in the minicuttings of Australian redcedar (Toona ciliata), however, longer photoperiod and temperatures, providing

the ministumps in the gutter system provided a greater production of minicuttings, than those ministumps in the garden with tubes system.

In the evaluation of macro and micronutrients contents there was a significative difference between cropping systems. In the semi-hydroponic cropping system there were greater amounts of de nitrogen, phosphorus, potassium, calcium, magnesium and copper, while in the conventional cropping system greater contents of zinc, iron and manganese were found (Table 3).

The conventional system, in the spring of 2013, summer, autumn and spring of 2014 presented a low productivity, differently from the semi-hydroponic system, which presented a high level of minicuttings. One of the factors that might be associated with the greater productivity in the Table 3. Contents of macro and micronutrients in the leaves of olive cultivar Arbequina kept in conventional and semi-hydroponic cropping systems. Pelotas-RS, Brazil

\begin{tabular}{|c|c|c|c|c|c|c|c|c|c|}
\hline \multirow{3}{*}{ Cropping systems } & $\mathrm{N}$ & $P$ & K & $\mathrm{Ca}$ & $\mathrm{Mg}$ & $\mathrm{Cu}$ & $\mathrm{Zn}$ & $\mathrm{Fe}$ & $M n$ \\
\hline & \multicolumn{9}{|c|}{ Total values } \\
\hline & --1- & $-\mathrm{g} . \mathrm{kg}$ & - & & & --- & $\mathrm{ng} \cdot \mathrm{kg}^{-1}$ & 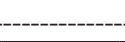 & \\
\hline Conventional & $5,54 b$ & $0,13 b$ & $4,58 b$ & $2,69 b$ & $0,71 b$ & $10,24 b$ & $30,16 a$ & $148,04 a$ & $28,39 a$ \\
\hline Semi-hydroponic & $19,58 a$ & $1,00 a$ & $14,56 a$ & $5,63 a$ & $1,17 a$ & $12,29 a$ & $21,11 \mathrm{~b}$ & $139,50 \mathrm{~b}$ & $19,42 \mathrm{~b}$ \\
\hline
\end{tabular}

semi-hydroponic system is the greater amount of nitrogen found in leaf analysis, since this chemical element is responsible for shoot growth (Table 3).

Other factors that might be related to the low productivity levels of the conventional system is the lesser number of times that the cropping system received the application of nutritive solution (every 15 days), compared with the semi-hydroponic system, which received a daily application of the solution. The container size to which the ministumps were transplanted might have contributed to this result, since their root system had a smaller space to develop, compared to the ministumps developed in flowerpot. According to Silva et al. (2012), as to clonal mini garden in gutter and in tubes, the last one had smaller productivity due to the smaller area compared to the gutter system, which reduces the difference of productivity between cropping systems per nursery area.

In the interaction cropping systems and collection seasons, for the variable survival of minicuttings, there were significative differences, with high survival percentages of minicuttings in the semi-hydroponic system superior to $70 \%$, while in the conventional system a high survival 
was only observed for the autumn and spring of 2014. Between collection seasons in the semihydroponic system all minicuttings had a high survival percentage. As for the conventional system, the seasons of autumn (86\%) and spring (85\%) of 2014 presented higher survival percentages. It was then verified that the conventional system presented a lower survival percentage than the semi-hydroponic system in the autumn (34\%) and spring of 2013 (17\%), beside the summer of 2014 (15\%) (Table 2).

Satisfactory results in cropping systems were reported with different vegetal species, as those reported by Silva et al. (2012), where they obtained $100 \%$ survival in minicuttings of Australian redcedar (Toona ciliata) in gutter and tubes minigardens. In this work, however, as for the conventional system, there was no high survival percentage in the autumn and spring of 2013 and summer of 2014. In a clonal minigarden of Grevillea robusta, Souza Junior et al. (2008), verified the survival of $100 \%$ of the ministumps after 15 collections, indicating that the adopted minigarden system, handling and mineral nutrition were efficient after successive material collections. The higher survival percentage observed in this work with olive mini garden, conducted in a semi-hydroponic system, is mainly related to the nutritional factor.

For the variable rooting percentage there was a significative difference between cropping systems. The semi-hydroponic system had higher rooting percentages in four out of five collection seasons (autumn and spring of 2013, summer and spring of 2014), with no difference observed in autumn 2014 compared to the conventional system. For the semi-hydroponic system, the most favorable rooting seasons were the spring $(92,5 \%)$, and the autumn of $2014(85,75 \%$, the autumn of $2013(84 \%)$ and the summer of 2014 (65,75\%), and the lowest rooting percentage in the spring of $2013(54,25 \%)$. As for the conventional system the season with higher rooting percentage was the autumn of 2014 , with $80 \%$ of rooting (Table 4).

According to the data obtained we could verify that all seasons were favorable to rooting in the semi-hydroponic system, and although the spring of 2013 has presented a lower rooting percentage compared to the remaining three seasons it is nonetheless a superior value

Table 4. Rooting percentage averages, number and length of roots $(\mathrm{cm})$ in Arbequina olive cultivar minicuttings in semi-hydroponic and conventional cropping systems in different seasons. Pelotas-RS, Brazil

\begin{tabular}{|c|c|c|c|c|c|c|}
\hline \multirow{2}{*}{$\begin{array}{c}\text { Seasons/ } \\
\text { Collection years }\end{array}$} & \multicolumn{2}{|c|}{$\begin{array}{c}\text { Rooting } \\
(\%)\end{array}$} & \multicolumn{2}{|c|}{ No of roots } & \multicolumn{2}{|c|}{ Length of roots $(\mathrm{cm})$} \\
\hline & $\begin{array}{c}\text { Semi- } \\
\text { Hydroponic }\end{array}$ & Conventional & $\begin{array}{l}\text { Semi- } \\
\text { Hydroponic }\end{array}$ & Conventional & $\begin{array}{c}\text { Semi- } \\
\text { Hydroponic }\end{array}$ & Conventional \\
\hline Autumn/2013 & $84 \mathrm{Aa}$ & $31 \mathrm{Bbc}$ & $5,46 \mathrm{Ab}$ & $1,66 \mathrm{Babc}$ & $1,53 \mathrm{Aa}$ & $0,37 \mathrm{Bb}$ \\
\hline Spring/2013 & $54,25 \mathrm{Ab}$ & $8 \mathrm{BC}$ & $1,94 \mathrm{AC}$ & $0,30 \mathrm{Ac}$ & $0,42 \mathrm{Aa}$ & $0,09 \mathrm{Ab}$ \\
\hline Summer/2014 & $65,75 \mathrm{Aa}$ & $13 \mathrm{BC}$ & $2,90 \mathrm{AC}$ & $0,68 \mathrm{Bbc}$ & $1,09 \mathrm{Aa}$ & $0,07 \mathrm{Bb}$ \\
\hline Autumn/2014 & $85,75 \mathrm{Aa}$ & $80 \mathrm{Aa}$ & $3,68 \mathrm{Abc}$ & $3,09 \mathrm{Aab}$ & $1,5 \mathrm{Aa}$ & $1,75 \mathrm{Aa}$ \\
\hline Spring/2014 & $92,5 \mathrm{Aa}$ & $49 \mathrm{Bb}$ & $8,65 \mathrm{Aa}$ & $3,4 \mathrm{Ba}$ & $1,03 \mathrm{Aa}$ & $0,68 \mathrm{Aab}$ \\
\hline $\mathrm{CV}(\%)$ & \multicolumn{2}{|c|}{29,03} & \multicolumn{2}{|c|}{19,56} & \multicolumn{2}{|c|}{66,46} \\
\hline
\end{tabular}

compared to those obtained in the four seasons of the conventional system. Based in these results it is verifiable that the semi-hydroponic cropping system influenced the rooting levels in olive minicuttings, probably due to the supplyment of greater amounts of most nutrients necessary to the ministumps growth (Table 3).

Rooting percentage is also related to the genetic potential. In research developed by Oliveira et al. (2012b), the authors obtained $77 \%$ of rooting in minicuttings of olive cultivar
Ascolano 315. According to Silva et al. (2012b), the collection season of olive minicuttings influences the formation of adventitious roots, and the rooting potential of minicuttings also varies within cultivars.

Minicuttings of Calophyllum brasiliense presented a high rooting level (>85\%) pointing that the management of ministumps in clonal mini garden provides buddings with good rooting conditions. According to the authors the homogenous rooting is attributed to the good 
nutritional status of parent plants in the clonal minigarden (Silva et al., 2010). Therefore, the higher rooting percentages obtained in the semihydroponic system are related to the adequate availability of nutrients found in this technique. To Wendling \& Xavier (2005), among the factors that might contribute to high rooting levels are good conditions of temperature and humidity, and the handling system to which the propagules are subjected, allied to the genetical potential of the adopted vegetative material, constituting a factor of great importance for the achievement of good results.

In the interaction of cropping systems and collection seasons there were significative differences regarding the number of roots. In the semi-hydroponic system there was a greater number of roots in three evaluated seasons: the autumn of 2013, summer and spring of 2014, compared to the conventional system. To both systems there were no differences in the spring of 2013 and the autumn of 2014. For the collection seasons there was a significative difference in the semi-hydroponic system, with a higher number in the spring of $2014(8,65)$ and lower numbers in the summer of 2014 and spring of 2013. In the conventional system the spring of $2014(3,4)$ and the autumn of $2014(3,09)$ we also the favorable seasons for this variable (Table 4).

With minicuttings of cultivar Arbequina, Cappellaro (2013) verified that the spring time presented a higher root number $(5,98)$, followed by the summer $(4,88)$ and winter $(2,37)$. In the present work the higher number of roots $(8,65)$ was obtained in the spring of 2014. Variations in the number of roots were also reported by Silva et al. (2012b), where they observed a great rooting variation in olive minicuttings. According to the authors the minicuttings collected in April had a greater rooting than those collected in August. In other works, variations within the same cultivar occur due to the time that the collection was performed. Resembling this work, Silva et al. (2012b), verified that olive cultivar Arbequina obtained 6 roots in April and 2,7 roots in August. For Alcântara et al. (2007), minicuttings which develop a higher quality rooting system, in terms of strength and uniformity, reflect positively in the survival and development of the seedling in the field.

In the interaction of cropping systems and collection seasons there are significative differences for root length. On the difference within systems, the semi-hydroponic was superior in root length in two collection seasons, the autumn of 2013 , with $1,53 \mathrm{~cm}$, and the summer of 2014 , with $1,09 \mathrm{~cm}$. However, as for the remaining three seasons there was no statistical difference. In the analysis of the collection seasons there are no differences for the semi-hydroponic cropping system, while there are differences in the conventional system, with higher values of root length in the autumn and spring of 2014, with $1,75 \mathrm{~cm}$ and $0,68 \mathrm{~cm}$, respectively (Table 4).

Results obtained by Cappellaro (2013) report the summer as the season with greater length $(2,74 \mathrm{~cm})$, followed by spring $(2,09 \mathrm{~cm})$ and winter $(1,09 \mathrm{~cm})$ for minicuttings of olive cultivar Arbequina. In this work, for both systems, the autumn of 2014 was the season with greater root length, and in summer good results were only obtained for the semi-hydroponic system, with $1,09 \mathrm{~cm}$. These differences in evaluated seasons are reported in other vegetal species. In a work developed in clonal minigarden in tubes with guava (Psidium guajava) Altoé et al. (2011), verified the root length in August, which reached $6,84 \mathrm{~cm}$, and in February, with $8 \mathrm{~cm}$. According to the authors, the difference among cultivars also influences in root length.

Rooted minicuttings from cropping systems presented $100 \%$ survival rate, with no statistical difference between cropping systems during the 90 evaluation days. According to Altoé et al. (2011), among the factors that might have contributed to the high levels of minicuttings survival are physiological, temperature, humidity and handling conditions to which the propagules were subjected during the experiment.

\section{Conclusion}

Until 90 evaluation days the ministumps of olive cultivar Arbequina presented a better initial development in length and budding number in the semi-hydroponic system, compared to the conventional cropping system.

The cultivation of ministumps of olive cultivar Arbequina in semi-hydroponic system 
presented a greater minicuttings productivity, allowing five collections of propagative material, during the evaluation seasons.

The minicuttings collected from the semihydroponic system provided the higher rooting percentages, in four out of five collections, than the conventional cropping system.

\section{Acknowledgments}

To the Coordenação de

Aperfeiçoamento de Pessoal de Nível Superior (Capes) for the scholarship concession.

To the Fundação de Amparo à Pesquisa do Estado do Rio Grande do Sul (FAPERGS) and Conselho Nacional de Desenvolvimento Científico e Tecnológico (CNPq).

\section{References}

Affonso, L.B. 2011. Propagação assexuada de araçazeiro. 53f. Dissertação (Mestrado em Agronomia) - Faculdade de Agronomia Eliseu Maciel, Universidade Federal de Pelotas, Pelotas, Brasil.

Affonso, L.B., Peil, R.M.N., Schuch, M.W., Cappellaro, T.H., Ozelame, G.L.C. 2015. Microjardim clonal de mirtileiro em sistema de cultivo sem solo. Revista Brasileira de Fruticultura 37:1037-1044.

Alcântara, G.B.de., Ribas, L.L.F., Higa, A.R., Zuffellato-Ribas, K.C., Koehler, H.S. 2007. Efeito da idade da muda e da estação do ano no enraizamento de miniestacas de Pinus taeda $\mathrm{L}$. Revista Árvore 31:399-404.

Altoé, J.A.A., Marinho, C.S., Terra, M.I.C., Carvalho, A.J.C. 2011 . Multiplicação de cultivares de goiabeira por miniestaquia. Bragantia 70:801809.

Batista, P.F., Maia, S.S.S., Coelho, M.F.B., Benedito, C.P., Guimarães, I.P. 2011. Propagação vegetativa de romã em diferentes substratos. Revista Verde 6:96-100.

Cappellaro, T.H. 2013. Produção de mudas de oliveira em sistemas de cultivo sem solo. 105f. (Tese de Doutorado) - Faculdade de Agronomia Eliseu Maciel, Universidade Federal de Pelotas, Pelotas, Brasil.

Cavalcanti Júnior, A.T. 2000. Formação dos jardins clonais na Embrapa Agroindústria Tropical. Embrapa Agroindústria Tropical, Fortaleza, Brasil. 4p. (Instruções Técnicas, 3).

Cruz, C. D. 2013. GENES - a software package for analysis in experimental statistics and quantitative genetics. Acta Scientiarum Agronomy 35:271-276.
Cunha, A.C.M.C.M.da., Paiva, H.N., Leite, H.G., Barros, N.F., Leite, F.P. 2009. Relações entre variáveis climáticas com produção e enraizamento de miniestacas de eucalipto. Revista Árvore 33:195-203.

Dias, P.C., Xavier, A., Oliveira, L.S., Paiva, H.N., Correia, A.C.G. 2012. Propagação vegetativa de progênies de meios-irmãos de angico-vermelho (Anadenanthera macrocarpa (Benth) Brenan) por miniestaquia. Revista Árvore 36:389-399.

Ferriani, A.P., Zuffellato-Ribas, K.C., Helm, C.V., Boza, A., Wendling, I., Koehler, H.S. 2011 . Produção de brotações e enraizamento de miniestacas de Piptocarpha angustifolia. Pesquisa Florestal Brasileira 31:257-264.

Nascimento, D.C., Schuch, M.W., Peil, R.M.N. 2011 . Enraizamento de microestacas de mirtileiro provenientes de microjardim clonal semihidropônico. Revista Brasileira de Fruticultura 33:1251-1256.

Oliveira, A.F.de., Chalfun, N.N.J., Alvarenga, A.A., Vieira Neto, J., Pio, R., Oliveira, D.L.de. 2009. Estaquia de oliveira em diferentes épocas, substratos e doses de AIB diluído em $\mathrm{NaOH}$ e álcool. Ciência e Agrotecnologia 33:79-85.

Oliveira, A.F.de., Vieira Neto, J., Villa, F., Silva, L.F.de.O. 2010. Espaçamento entre plantas no desempenho de jardim clonal de cultivares de oliveira. Scientia Agraria 11:317-322.

Oliveira, M.C., Ramos, J.D., Pio, R., Cardoso, M.G. 2012. Características fenológicas e físicas e perfil de ácidos graxos em oliveiras no sul de Minas Gerais. Pesquisa Agropecuária Brasileira 47:3035. a.

Oliveira, M.C., Ramos, J.D., Pio, R., Santos, V.A., Silva, F.O.dos.R. 2012. Enraizamento de estacas em cultivares de oliveiras promissores para a Serra da Mantiqueira. Ceres 59:147-150. b.

Rocha, J.H.T., Backes, C., Borelli, K., Prieto, M.R., Santos, A.J.M., Godinho, T.O. 2013. Concentração de nutrientes e intensidade de cor verde em miniestacas de eucalipto. Bioscience Journal 29:1848-1856.

Schuch, M.W., Peil, R.M.N. 2012. Soilless cultivation systems: A new approach in fruit plants propagation in the south of Brazil. In: International Symposium on Advanced Technologies and management towards sustainable greenhouse ecosystems-Green Syszoll. Acta Horticulturae 952:877-883.

Silva, R.L.da., Oliveira, M. L.de., Monte, M.A., Xavier, A. 2010. Propagação clonal de guanandi (Calophyllum brasiliense) por miniestaquia. Agronomía Costarricense 34:99-104. 
Silva, M.P.S.da., Barroso, D.G., Souza, J.S.de., Ferreira, D.A., Carneiro, J.G.A. 2012. Enraizamento de miniestacas e produtividade de minicepas de cedro australiano manejadas em canaletões e tubetes. Ciência Florestal 22:703-713.

Silva, L.F.O.de., Oliveira, A.F.de., Pio, R., Alves, T.C., Zambon, C.R. 2012. Variação na qualidade do azeite em cultivares de oliveira. Bragantia 71:202-209. a.

Silva, L.F.de.O., Oliveira, A.F.de., Pio, R., Zambon, C.R., Oliveira, D.L. 2012. Enraizamento de estacas semilenhosas de cultivares de oliveira. Bragantia 71:488-492. b.

Souza Junior, L.de., Quoirin, M., Wendling, I. 2008. Miniestaquia de Grevillea robusta A. Cunn. a partir de propágulos juvenis. Ciência Florestal 18:455-460.

Wendling, I., Xavier, A. 2005. Influência da miniestaquia seriada no vigor radicular de clones de Eucalyptus grandis. Revista Árvore 29:681-689. 